\title{
Childhood immunizations in China: disparities in health care access in children born to North Korean refugees
}

\author{
Hyun Jung Chung ${ }^{1,2^{*}}$, Seung Hyun $\mathrm{Han}^{3}$, Hyerang $\mathrm{Kim}^{4}$ and Julia L. Finkelstein ${ }^{1}$
}

\begin{abstract}
Background: Childhood immunization rates are at an all-time high globally, and national data for China suggests close to universal coverage. Refugees from North Korea and their children may have more limited health care access in China due to their legal status. However, there is no data on immunization rates or barriers to coverage in this population.

Methods: This study was conducted to determine the rates and correlates of immunizations in children ( $\geq 1$ year) born to North Korean refugees in Yanbien, China. Child immunization data was obtained from vaccination cards and caregiver self-report for 7 vaccines and 1:3:3:3:1 series. Age-appropriate vaccination rates of refugee children were compared to Chinese and migrant children using a goodness-of-fit test. Logistic regression was used to determine correlates of immunization coverage for each vaccine and the 1:3:3:3:1 series.

Results: Age-appropriate immunization coverage rates were significantly lower in children born to North Korean refugees (12.1-97.8\%), compared to Chinese (99\%) and migrant (95\%) children. Increased father's age and having a sibling predicted significantly lower vaccination rates.

Conclusions: Children born to North Korean refugees had significantly lower immunization rates, compared to Chinese or migrant children. Further research is needed to examine barriers of health care access in this high-risk population.
\end{abstract}

Keywords: Immunization, Child health, Health disparities, North Korean refugees in China

\section{Background}

North Korea has faced famine, severe food shortages, persecution, and human rights violations, and in the late 1990s thousands of North Koreans fled across the border into China [1-3]. The Chinese government classifies North Korean refugees as illegal economic migrants, differentiating them from other refugees $[2,4]$. Northeast China has a 14:1 male:female ratio, which drives a demand for North Korean "bride-slaves" sold to Chinese men [5-7]. Children born to North Korean refugee women and Chinese men are not recognized as citizens because of the legal status of their mothers. These "stateless" children are excluded from the public

\footnotetext{
* Correspondence: hc473@cornell.edu

${ }^{1}$ Cornell University, Ithaca, NY, USA

${ }^{2}$ Yonsei University College of Medicine, 50-1 YonseiRo SeodaemunGu,

120-752 Seoul, South Korea

Full list of author information is available at the end of the article
}

health care system $[7,8]$. A "stateless" person is defined in the 1954 Convention relating to the Status of Stateless Persons as "a person who is not considered as a national by any State under the operation of its law".

Routine childhood vaccinations are among the most cost-effective preventive health services [9]. Childhood immunization rates are at an all-time high worldwide, and national data for China suggests close to universal immunization coverage [10-12]. The Chinese government has strived to exceed the goal of $90 \%$ immunization rates for children. According to the review of surveillance data from the China Center for Disease Control and Prevention, reported immunization rates for all required childhood vaccines has been $99 \%$ in China every year since 2005 [13]. National-level data may conceal disparities in immunization rates, particularly in marginalized and minority sub-populations [9]. 
For example, in a previous study of immunization status and risk factors among children in Bejing, China, migrant children had significantly lower age-appropriate immunization rates for the 1:3:3:3:1 series, compared to registered Chinese children [14]. Similarly, in a study of immunization coverage and its determinants among children in Zhejiang, China, $54.6 \%$ of migrant children had age-appropriate vaccinations, compared to $92.9 \%$ of Chinese children at 12 months of age [15].

In China, registered children have had access to free vaccinations since the mid-1990s; all vaccines are provided free of charge in public clinics, regardless of insurance status [14]. The Chinese government has developed specific programs to provide vaccinations to migrant children, including house-to-house visits by health care workers to identify incompletely vaccinated children and immunize them in clinics. Children born to North Korean refugee women and Chinese men, however, are not recognized by the government as citizens and are excluded from public health care system [7, 8]. Although there is limited data on this sub-population, it is estimated that 10,000 to 50,000 children are born each year to North Korean refugee women and Chinese men.

Refugees from North Korea and their children may have more limited health care access in China due to their legal status. However, there is no data on the immunization rates or barriers to vaccination coverage in this high-risk population. The objective of this study was to determine the rates of immunization in children born to North Korean refugee women and Chinese men in China, and to identify predictors of vaccination status.

\section{Methods}

\section{Design}

A cross-sectional survey was administered to 91 North Korean refugee caregivers of children over 12 months of age, residing in the Yanbien prefecture in northwest China. A total of 200 North Korean refugees were approached and screened for potential participation in this study; 157 individuals were eligible to participate, and 91 caregivers consented to participate in this study and responded to the questionnaire. A Consort diagram of the participant recruitment is presented in Fig. 1. Immunization rates, and socio-demographic, health, and obstetric history data were collected from all participants. The study protocol was explained in detail to the caregivers, and informed written consent was obtained prior to study enrollment. The study protocol was approved by the Institutional Review Board for human participants at Cornell University, and was also approved by the appropriate local authorities in China with permission letters from independent local community NGO leaders stating that this research is in keeping with local social standards and expectations.

\section{Participant characteristics}

The participants in this study were primary caregivers of children born to North Korean refugee women and Chinese men. A primary caregiver was defined as a parent, a grandparent, or another close relative who was caring for the child at the time of the study. Inclusion criteria were: having a child 12 months of age and older born to a North Korean refugee mother (who crossed the North Korean-Chinese border in the past 20 years) and a Chinese man, residence in the Yanbien prefecture

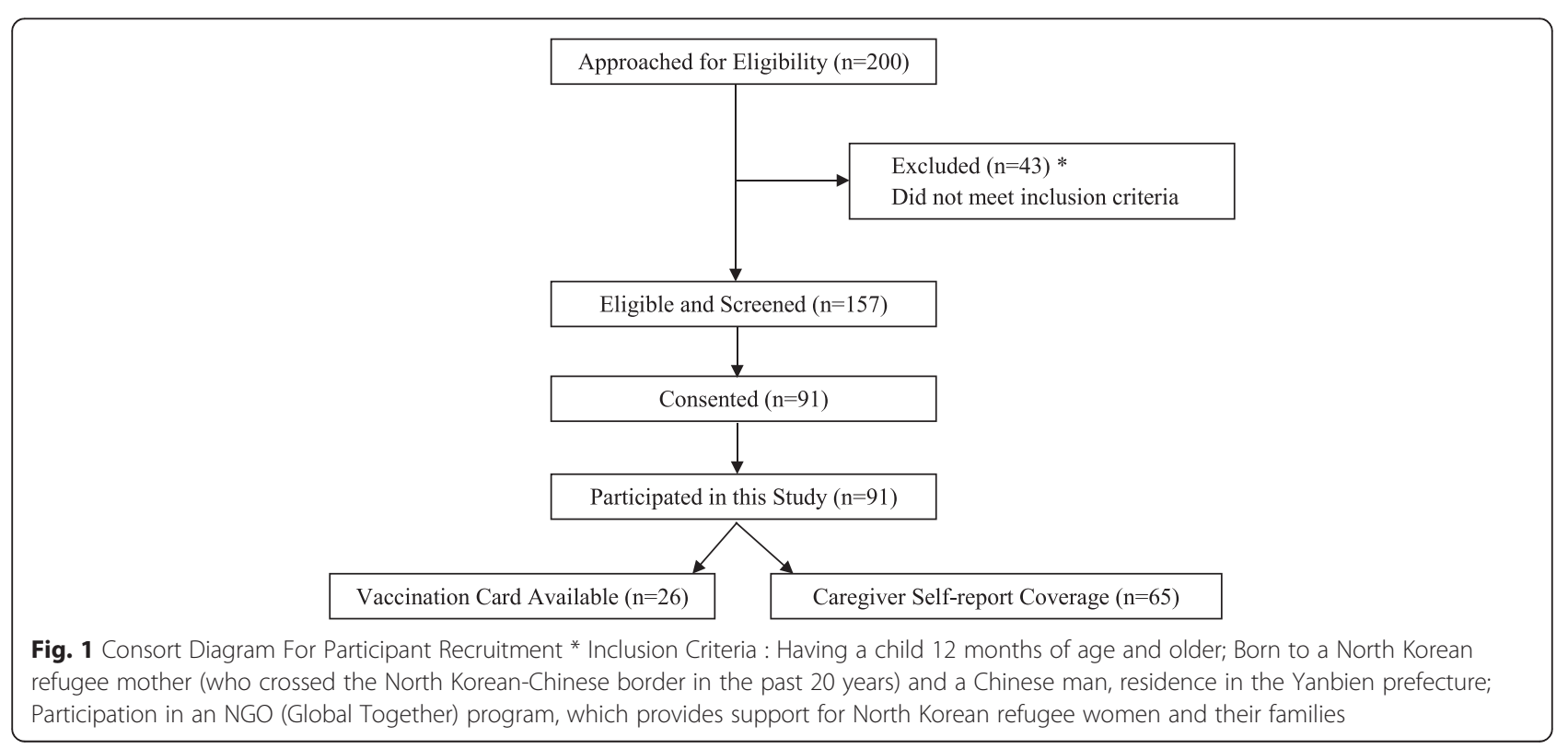


in China, and participation in an NGO (Global Together) program which provides support for North Korean refugee women and their families. The NGO provides services to approximately $20 \%$ of the population of North Korean refugees in this area. This NGO provides services to approximately $20 \%$ of the population of North Korean refugees in this area. Almost all North Korean refugees reach out to local Korean churches in China for assistance and to register their names in this system, and the NGO randomly selected individuals from this population. In addition to random selection of potential participants, there are no major differences between those who participate in the NGO program and those who do not. This age group was selected based on the Ministry of Health guidelines in China that require completion of primary immunizations (1:3:3:3:1 series) by 12 months of age [11]. The vaccination requirements and age-appropriate schedule are presented in Table 1.

\section{Data collection}

A structured questionnaire was administered to 91 primary caregivers of Korean-Chinese children from June to August, 2010. This questionnaire comprised 32 closed-ended items, including vaccination status, sociodemographic (e.g., child's gender, age, place of birth, maternal and paternal educational level, father's region of origin) data, health (e.g., health condition at birth, current health status) data, obstetric history (e.g., previous history of miscarriage), and origin of birth. The questionnaire was given face-to-face in Yanbien to caregivers by a trained research assistant from the NGO.

\section{Immunization data}

Child immunization data was extracted from vaccination cards or mainly assessed by caregiver self-report, due to the low availability of vaccination card. Among 91 participants, 23 participants had vaccination cards available, and 68 participants depended on caregiver's written self-reports as presented in Fig. 1. The immunization rates of children with vaccination cards and those without vaccination cards were similar for each of the vaccines $(p>0.05)$ (Table 2). Data for seven vaccines were collected, including the five vaccines as part of the 1:3:3:3:1 series: BCG (tuberculosis), diphtheria-tetanuspertussis (DTP), hepatitis B (HBV), measles-mumpsrubella (MMR), polio (POL); and two additional vaccines, varicella (VAR) and Japanese encephalitis (JE).

The vaccination schedule for the first 12 months of life recommended by the World Health Organization (WHO) and the Ministry of Health $(\mathrm{MOH})$ in China in 2012 is presented in Table 1. The 1:3:3:3:1 series includes one dose of BCG (at 1 month of age), three doses of HBV (birth, 1 month, and 6 months), three doses of POL (2, 3, and 4 months), three doses of DTP (3, 4, and 5 months), and one dose of MMR (8 months) [15].

Immunization data for local Chinese children were obtained from the publically available WHO national immunization coverage datasets for China. Immunization data for children aged 12 months and older was selected from 2010, to compare vaccination rates to data from local children from the same year and age group [12]. Immunization data for migrant children were obtained from a previous study published by $\mathrm{Hu}$ et al. in 2011 [15]. In this study, a household cluster sampling survey was administered to primary caregivers of 2,632 migrant children aged 12 to 35 months in 2010, using in-person interviews [15].

\section{Data analysis}

Child immunization data was categorized as ageappropriate for each vaccine in Table 1 , and for the 1:3:3:3:1 series, based on the monthly vaccination schedule (i.e., correct number and timing of all doses). Rates

Table 1 Immunization schedule for Children (2012, WHO, MOH China)

\begin{tabular}{|c|c|c|c|c|c|c|c|c|c|c|c|c|c|}
\hline Vaccine* & Birth & 1 & 2 & 3 & 4 & 5 & 6 & 8 & 12 & 18 & 24 & 48 & 72 \\
\hline $1: 3: 3: 3: 1$ & & & & & & & & & & & & & \\
\hline BCG & $1 / 1$ & & & & & & & & & & & & \\
\hline HBV & $1 / 3$ & $2 / 3$ & & & & & $3 / 3$ & & & & & & \\
\hline POL & & & $1 / 4$ & $2 / 4$ & $3 / 4$ & & & & & & & $4 / 4$ & \\
\hline DTP & & & & $1 / 4$ & $2 / 4$ & $3 / 4$ & & & & $4 / 4$ & & & $\mathrm{Td}$ \\
\hline MMR & & & & & & & & $1 / 2$ & & $2 / 2$ & & & \\
\hline VAR & & & & & & & & & $1 / 1$ & & & & \\
\hline JE & & & & & & & & $1 / 2$ & & & $2 / 2$ & & \\
\hline
\end{tabular}


Table 2 Child Immunization Rates by Vaccination Card Status

\begin{tabular}{|c|c|c|c|}
\hline Vaccines & $\begin{array}{l}\text { Children Immunized (\%) } \\
\text { with vaccination card } \\
(n=26)\end{array}$ & $\begin{array}{l}\text { Children Immunized (\%) } \\
\text { without vaccination card } \\
(n=65)\end{array}$ & $P$-value \\
\hline BCG & $92.3(24 / 26)$ & $100(65 / 65)$ & 0.16 \\
\hline DTP & $38.5(10 / 26)$ & $18.4(12 / 65)$ & 0.29 \\
\hline HBV & $73.0(19 / 26)$ & $60.0(39 / 65)$ & 0.31 \\
\hline MMR & $76.9(20 / 26)$ & $90.8(59 / 65)$ & 0.17 \\
\hline $\mathrm{POL}$ & $19.2(5 / 26)$ & $9.23(6 / 65)$ & 0.64 \\
\hline
\end{tabular}

$B C G$ tuberculosis vaccine; DTP diphtheria-tetanus-pertussis vaccine, $H B V$ hepatitis $B$ vaccine, $M M R$ measles-mumps-rubella vaccine, $P O L$ polio vaccine, $T d$ Tetanus toxoid vaccine

of vaccines were analyzed for each of the seven vaccines, and for the 1:3:3:3:1 series. Age-appropriate vaccination rates for children in the current study were compared to local Chinese children (WHO) [12] and migrant children (Hu et al) [15] using a goodness-of-fit test. Logistic regression was used to determine predictors of immunization status for children for each of the seven vaccines and for the 1:3:3:3:1 series. Variables with univariate $p$-values of less than 0.20 were included in each of the multivariate regression models $(p<0.10, p<0.05$ models) and retained if their $p$-values were less than 0.05. All statistical analyses were performed using SPSS software, Version 18.0 (SPSS Inc., Chicago, IL, USA).

\section{Results}

The characteristics of the 91 children and their parents in this study are presented in Table 3. A total of $52.7 \%(n=$ $48)$ of children were female; and $81.3 \%(n=74)$ had a parent for a primary caregiver. The average age of mothers was 37.2 (SD: 5.8) years and the average age of fathers was 41.1 (SD: 6.3) years; $39.6 \%(n=36)$ of participants had annual income of less than 3000 Yuan (Approximately 453 USD). A total of $69.2 \%(n=63)$ of fathers were Han in origin, and $30.8 \%(n=28)$ were Chinese Korean (Chosun); $90.1 \%(n=82)$ of fathers had elementary school education level or no formal education.

Immunization rates for Korean-Chinese, local Chinese, and migrant children are presented in Table 4 . Immunization rates for Korean-Chinese children were significantly lower than for local Chinese children, including DTP $(24.2 \%$ vs. $99.0 \%$; $p<0.001)$, HBV (63.7 \% vs. $99.0 \% ; P<0.001)$, MMR (86.8 \% vs. $96.0 \% ; P=0.005)$, and POL $(12.1 \%$ vs. $99.0 \% ; p<0.001)$ were significantly lower in the Korean-Chinese children, compared to local Chinese children. The rates of BCG were not significantly different (97.8 \% vs. $99.0 \%$; $p=0.22)$. Immunization rates for Korean-Chinese children were also significantly lower than migrant children, including DTP (24.2\% vs. $96.3 \%$; $p<0.001)$, HBV (63.7 \% vs. $92.1 \% ; p<0.001)$, and POL (95.2 \% vs. $12.1 \% ; p<0.001$ ) (Table 4 ). The immunization rates for the 1:3:3:3:1 series for Korean-Chinese children
(14.3\%) were significantly lower than for local Chinese children $(92.8 \%, p<0.001)$ and migrant children $(54.6 \%$, $p<0.001)$. The immunization rates for Korean-Chinese, Chinese, and migrant children are presented for each vaccine in Fig. 2. The immunization rates of children with vaccination cards and those without vaccination cards were similar for each of the vaccines $(p>0.05)$ (Table 2).

The univariate and multivariate correlates of immunization rates for Korean-Chinese children for each of the seven vaccines and for the 1:3:3:3:1 series are presented in Table 5. Having at least one sibling (OR: 0.16, 95 \% CI: 0.03-0.74, $p<0.05$ ) was associated with significantly lower odds of being vaccinated for HBV. Greater paternal age $(>40)$ was associated with significantly lower odds of being vaccinated for VAR (OR: 0.10, 95 \% CI: 0.01-0.95, $p<0.05$ ). Also, greater paternal age $(>40)$ was associated with significantly lower odds of being vaccinated for JE (OR: 0.41, 95 \% CI: 0.16-1.01, $p<0.05)$. Maternal history of miscarriage was associated with increased likelihood of having POL vaccine (OR: 12.51, $95 \% \mathrm{CI}: 3.03-51.66, p<0.05)$ and increased likelihood of having the complete 1:3:3:3:1 series (OR: 7.11, 95 \% CI: 2.01-25.13, $p<0.05$ ) (Table 5).

\section{Discussion}

\section{Main findings of this study}

In this study, children born to North Korean refugee women and Chinese men had significantly lower rates of immunizations, compared to Chinese or migrant children. Korean-Chinese children had significantly lower immunization rates for diphtheria-tetanus-pertussis, hepatitis B, measles-mumps-rubella, and polio compared to locally registered Chinese children; and lower rates of immunization for diphtheria-tetanus-pertussis, hepatitis $\mathrm{B}$, and polio, compared to migrant children. In contrast, rates of single-dose BCG were similarly high in all children. Increased paternal age and having a sibling were associated with lower odds of being vaccinated, while maternal history of miscarriage was associated with increased likelihood of children being vaccinated.

\section{What is already known on this topic}

Vaccines are the most cost-effective interventions for child survival, and access to essential childhood vaccinations is considered a human right. $[9,16]$ Childhood immunization rates are at an all-time high worldwide, and national data for China suggests close to universal immunization coverage [10-12]. However, overall global and national-level immunization rate data may conceal disparities in vaccination rates at sub-national levels [17], particularly in marginalized and minority subpopulations [9].

Low rates of immunization coverage have been reported in previous studies in China among migrant 
Table 3 Characteristics of the study population $(n=91)$

\begin{tabular}{ll}
\hline Variable & Mean (SD) or $n$ \\
$(\%)$
\end{tabular}

Socio-demographic

Gender of Child

\begin{tabular}{|c|c|c|}
\hline & Male & $43(47.3 \%)$ \\
\hline & Female & $48(52.7 \%)$ \\
\hline \multirow[t]{4}{*}{ Age (years) } & & $9.5(3.1)$ \\
\hline & $<8$ & $13(14.3 \%)$ \\
\hline & $8-11$ & $51(56.0 \%)$ \\
\hline & $\geq 12$ & 27 (29.7\%) \\
\hline $\begin{array}{l}\text { Total number of interracial } \\
\text { children }\end{array}$ & & $91(100.0 \%)$ \\
\hline \multicolumn{3}{|l|}{ Birthplace } \\
\hline & Heilong Jiang & $30(33.0 \%)$ \\
\hline & Liaoning & $17(29.7 \%)$ \\
\hline & Jilin & $34(37.3 \%)$ \\
\hline \multicolumn{3}{|l|}{ Primary caregiver } \\
\hline & Parent & $74(81.3 \%)$ \\
\hline & Grandparent & $4(4.4 \%)$ \\
\hline & Other relative & $13(14.3 \%)$ \\
\hline \multirow[t]{3}{*}{ Mother's age (years) } & & $37.2(5.8)$ \\
\hline & $<40$ & $60(65.9 \%)$ \\
\hline & $\geq 41$ & $31(34.1 \%)$ \\
\hline \multirow[t]{3}{*}{ Father's age (years) } & & $41.1(6.3)$ \\
\hline & $<40$ & $33(36.3 \%)$ \\
\hline & $\geq 41$ & $58(63.7 \%)$ \\
\hline \multicolumn{3}{|l|}{ Father's region of origin } \\
\hline & Han & $63(69.2 \%)$ \\
\hline & $\begin{array}{l}\text { Chinese-Korean } \\
\text { (Chosun) }\end{array}$ & 28 (30.8\%) \\
\hline
\end{tabular}

Father's educational level

$\begin{array}{lll} & \text { No formal education } & 8(8.8 \%) \\ & \text { Elementary school } & 74(81.3 \%) \\ & \text { Middle school } & 7(7.7 \%) \\ & \text { High school } & 2(2.2 \%) \\ \text { Annual income }\left(\text { Yuan }^{\mathrm{a}}\right) & & 3544.0(1837.3) \\ & & 36(39.6 \%) \\ & 30000 & 48(52.7 \%) \\ & \geq 6000 & 7(7.7 \%)\end{array}$

Siblings

$\begin{array}{ll}\text { No } & 74(81.3 \%) \\ \text { Yes } & 17(18.6 \%)\end{array}$

Health-related

Health condition at birth (Reported by caregiver)

$\begin{array}{ll}\text { Poor } & 11(12.0 \%) \\ \text { Good } & 80(88.0 \%)\end{array}$

Table 3 Characteristics of the study population $(n=91)$ (Continued)

Present health condition (Reported by caregiver)

$\begin{array}{ll}\text { Very poor } & 1(1.1 \%) \\ \text { Poor } & 4(4.4 \%) \\ \text { Good } & 70(76.9 \%) \\ \text { Very good } & 16(17.6 \%)\end{array}$

Vaccination diary available

$\begin{array}{ll}\text { No } & 65(71.4 \%) \\ \text { Yes } & 26(28.6 \%)\end{array}$

Maternal history of

miscarriage

\begin{tabular}{cc} 
No & $78(85.7 \%)$ \\
Yes & $13(14.3 \%)$ \\
\hline
\end{tabular}

${ }^{a} 1$ US Dollar was equivalent to approximately 6.62 Yuan at time of data collection

children $[14,15]$ and in other resource-limited settings in South-East Asia and Sub-Saharan Africa [17]. In a previous study among children in Zhejiang, China, vaccination rates were significantly lower in migrant children, compared to local Chinese children [15]. At eight months of age, $42.2 \%$ of migrant children were ageappropriately vaccinated for the 1:3:3:3:1 series, compared to $69.7 \%$ of local Chinese children. This gap in vaccination coverage increased by 12 months of age: only $54.6 \%$ of migrant children completed ageappropriate vaccinations for the 1:3:3:3:1 series by 12 months, compared to $92.9 \%$ of local Chinese children [15]. Also, in a research study conducted among migrant children in Beijing, China, migrant children had significantly lower immunization rates compared to registered Chinese children (65\% vs. $96 \%$ ); authors concluded that interventions were needed for migrant children to achieve universal immunization coverage.

In studies examining barriers to immunization coverage in children, parental educational level $[18,19]$, number of siblings in household [20], other socioeconomic factors [21-23], distance and cost [22] have been identified as barriers. Other studies have identified parental perception, health beliefs, and attitudes toward child immunizations as important predictors of completion of age-appropriate immunizations $[24,25]$. Also, in a research study conducted among migrant children in Beijing, China, primary caregiver's age, educational level, and awareness of the importance of immunization were important predictors of immunization status [14].

\section{What this study adds}

This is the first study to examine the rates of immunization in children born to North Korean refugee women and Chinese men. Additionally, this study 
Table 4 Vaccine Coverage: comparing immunization rates of interracial children to local Chinese and migrant children

\begin{tabular}{|c|c|c|c|c|c|c|c|c|c|c|}
\hline \multirow[b]{2}{*}{ Vaccines $^{\mathrm{b}}$} & \multicolumn{5}{|c|}{ Children Immunized (\%) } & \multicolumn{5}{|c|}{ Children Immunized (\%) } \\
\hline & $\begin{array}{l}\text { Local Chinese } \\
(n=1,341,335,000)\end{array}$ & $\begin{array}{l}\text { Interracial } \\
(n=91)\end{array}$ & Z & $P$-value & $\begin{array}{l}\text { Upper } \\
\text { conf } \\
\text { bound }\end{array}$ & $\begin{array}{l}\text { Migrant } \\
(n=2,632)\end{array}$ & $\begin{array}{l}\text { Interracial } \\
(n=91)\end{array}$ & Z & $P$-value & $\begin{array}{l}\text { Upper } \\
\text { conf } \\
\text { bound }\end{array}$ \\
\hline $\mathrm{BCG}$ & $99.0 \%$ & $97.8(89)$ & -0.78 & 0.218 & 0.013 & $92.8 \%$ & $97.8(89)$ & 3.253 & 0.999 & 0.075 \\
\hline DTP & $99.0 \%$ & $24.2(22)^{b}$ & -16.6 & $<0.001$ & -0.674 & $96.3 \%$ & $24.2(22)^{b}$ & -16 & $<0.001$ & -0.647 \\
\hline HBV & $99.0 \%$ & $63.7(58)^{b}$ & -7.00 & $<0.001$ & -0.270 & $92.1 \%$ & $63.7(58)^{b}$ & -5.63 & $<0.001$ & -0.201 \\
\hline MMR & $96.0 \%$ & $86.8(79)^{b}$ & -2.59 & 0.005 & -0.034 & $92.1 \%$ & $86.8(79)$ & -1.49 & 0.068 & 0.006 \\
\hline $\mathrm{POL}$ & $99.0 \%$ & $12.1(11)^{b}$ & -25.40 & $<0.001$ & -0.813 & $95.2 \%$ & $12.1(11)^{b}$ & -24.3 & $<0.001$ & -0.775 \\
\hline
\end{tabular}

${ }^{\mathrm{b}} B C G$ tuberculosis, DTP diphtheria-tetanus-pertussis, $H B V$ hepatitis $\mathrm{B}, M M R$ measles-mumps-rubella, $P O L$ polio

The numbers in parentheses in the column for Interracial Children represent the number of children receiving the full series of each vaccine

identified correlates and potential barriers to vaccination status. Korean-Chinese children had significantly lower vaccination rates, compared to local registered Chinese children or migrant children. Findings indicate that health disparities exist in children born to North Korean refugees and Chinese men, and suggest that this may be a high-risk population, which warrants further investigation.

In the present study, increased father's age was associated with significantly lower likelihood of being vaccinated. This is consistent with findings from a previous study among migrant children in Bejing, China [14]. Other studies have found that increased parental education [18] is associated with increased likelihood of childhood immunizations. Together, findings suggest paternal sociodemographic factors may be an important correlate of child vaccination status. Findings are also consistent with previous studies that found that increased number of siblings in a family was associated with increased odds of not being vaccinated [19].

In this study, maternal history of miscarriage was associated with increased likelihood of children being vaccinated. Although this has not been observed in previous studies, other studies have identified parental perception, health beliefs, and attitudes toward child immunizations are important predictors of completion of ageappropriate immunizations [24, 25]. It is possible that a previous miscarriage may influence parental attitudes, beliefs regarding health services, perceptions toward child immunizations, or health-seeking behaviors.

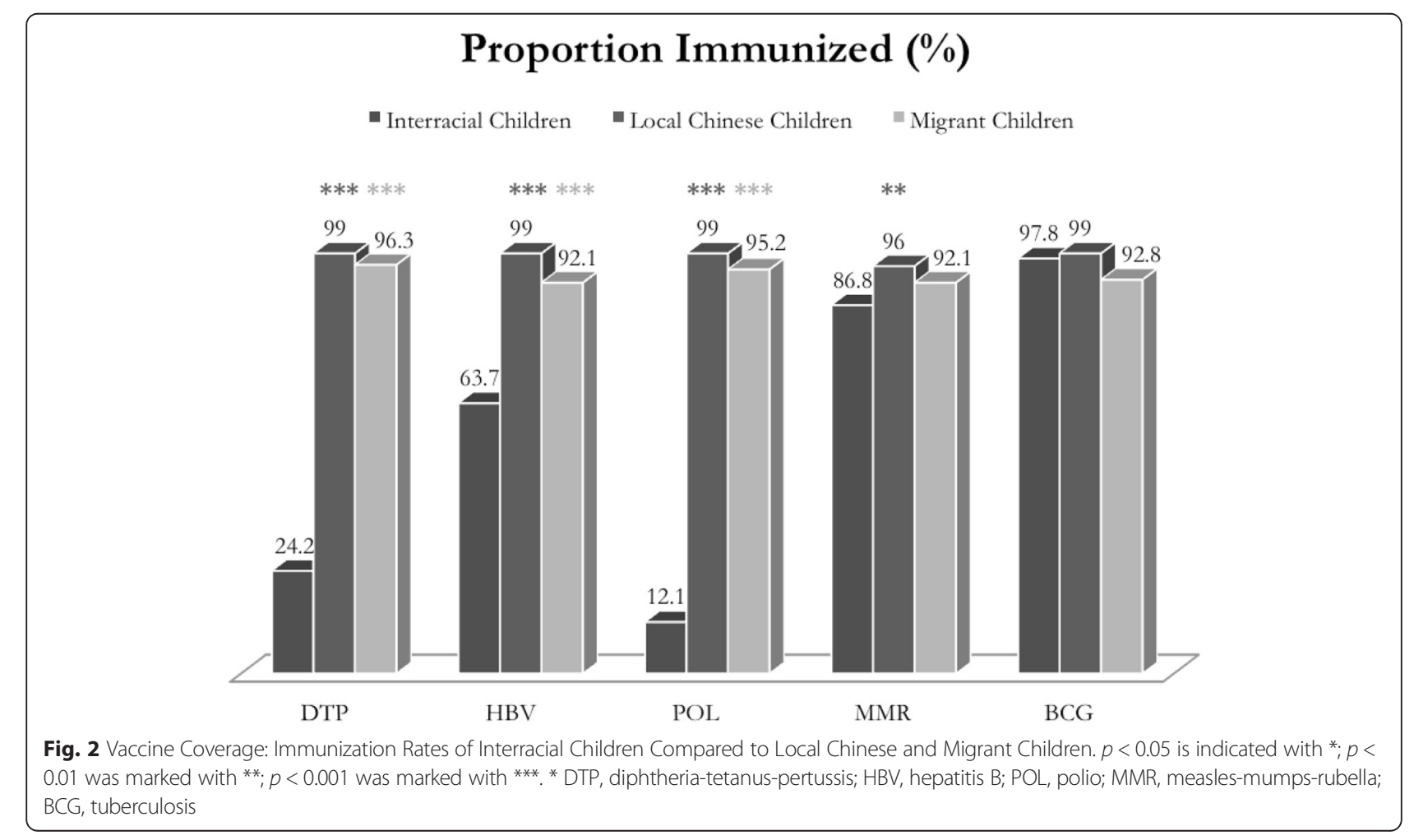


Table 5 Univariate and multivariate predictors of vaccination coverage

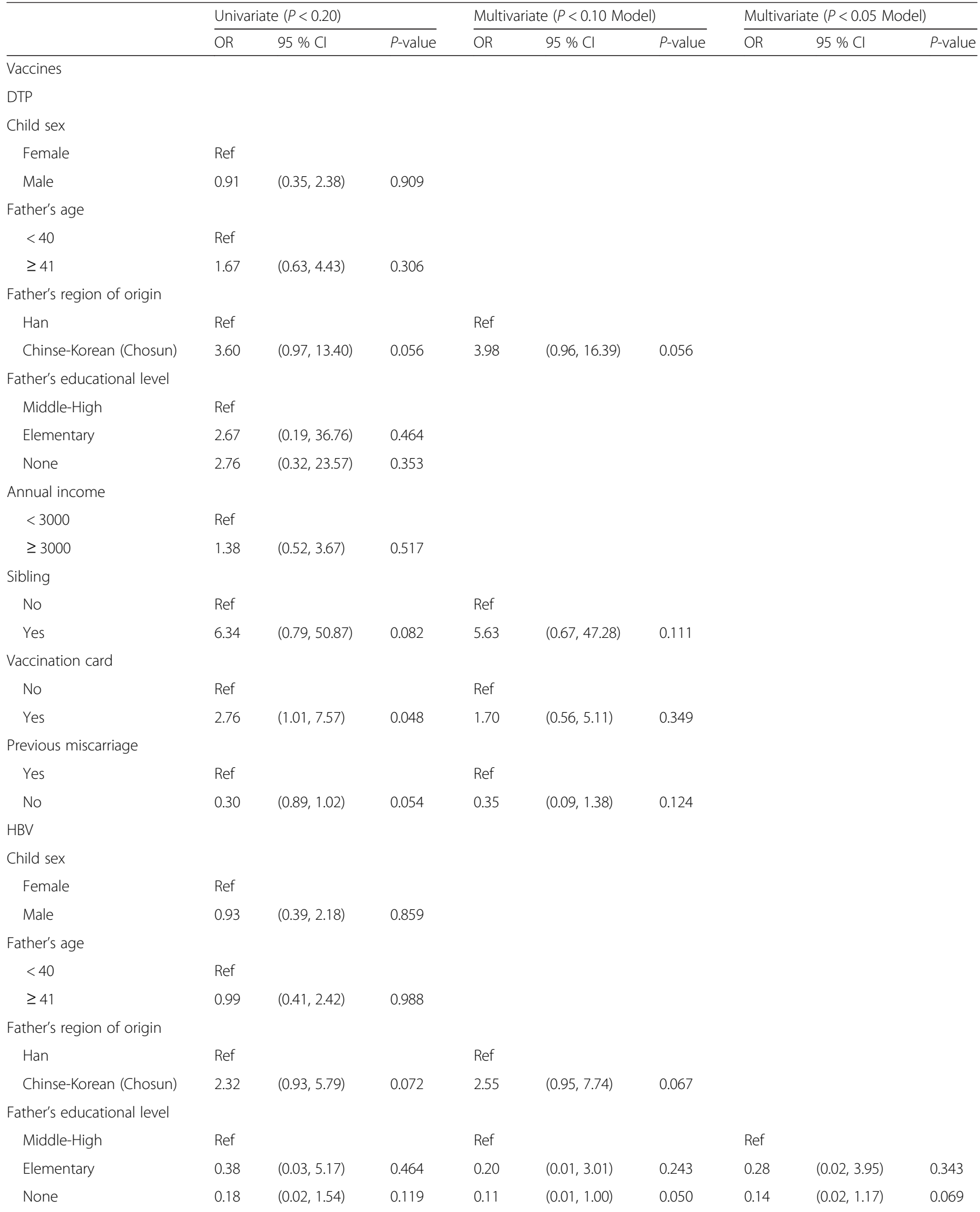


Table 5 Univariate and multivariate predictors of vaccination coverage (Continued)

\begin{tabular}{|c|c|c|c|c|c|c|c|c|c|}
\hline \multicolumn{10}{|l|}{ Annual income } \\
\hline$<3000$ & Ref & & & & & & & & \\
\hline$\geq 3000$ & 0.68 & $(0.29,1.63)$ & 0.387 & & & & & & \\
\hline \multicolumn{10}{|l|}{ Sibling } \\
\hline No & Ref & & & Ref & & & Ref & & \\
\hline Yes & 0.19 & $(0.04,0.87)$ & 0.032 & 0.16 & $(0.03,0.78)$ & 0.021 & 0.16 & $(0.03,0.74)$ & 0.019 \\
\hline \multicolumn{10}{|l|}{ Vaccination card } \\
\hline No & Ref & & & & & & & & \\
\hline Yes & 0.84 & $(0.43,2.87)$ & 0.836 & & & & & & \\
\hline \multicolumn{10}{|l|}{ Previous miscarriage } \\
\hline Yes & Ref & & & & & & & & \\
\hline No & 1.12 & $(0.33,3.74)$ & 0.859 & & & & & & \\
\hline \multicolumn{10}{|l|}{ MMR } \\
\hline \multicolumn{10}{|l|}{ Child sex } \\
\hline Female & Ref & & & & & & & & \\
\hline Male & 0.88 & $(0.26,2.97)$ & 0.838 & & & & & & \\
\hline \multicolumn{10}{|l|}{ Father's age } \\
\hline$<40$ & Ref & & & & & & & & \\
\hline$\geq 41$ & 0.77 & $(0.22,2.65)$ & 0.677 & & & & & & \\
\hline \multicolumn{10}{|l|}{ Father's region of origin } \\
\hline Han & Ref & & & & & & & & \\
\hline Chinse-Korean (Chosun) & 1.15 & $(0.32,4.17)$ & 0.836 & & & & & & \\
\hline \multicolumn{10}{|l|}{ Father's educational level } \\
\hline Middle-High & Ref & & & Ref & & & & & \\
\hline Elementary & 3.50 & $(0.28,43.16)$ & 0.328 & 3.90 & $(0.30,50.59)$ & 0.298 & & & \\
\hline None & 4.13 & $(0.86,19.79)$ & 0.077 & 3.50 & $(0.70,17.60)$ & 0.128 & & & \\
\hline \multicolumn{10}{|l|}{ Annual income } \\
\hline$<3000$ & Ref & & & & & & & & \\
\hline$\geq 3000$ & 0.90 & $(0.26,3.10)$ & 0.873 & & & & & & \\
\hline \multicolumn{10}{|l|}{ Sibling } \\
\hline No & Ref & & & & & & & & \\
\hline Yes & 1.55 & $(0.37,6.46)$ & 0.549 & & & & & & \\
\hline \multicolumn{10}{|l|}{ Vaccination card } \\
\hline No & Ref & & & Ref & & & & & \\
\hline Yes & 0.34 & $(0.10,1.17)$ & 0.087 & 0.37 & $(0.10,1.33)$ & 0.127 & & & \\
\hline \multicolumn{10}{|l|}{ Previous miscarriage } \\
\hline Yes & Ref & & & & & & & & \\
\hline No & 2.30 & $(0.53,9.96)$ & 0.265 & & & & & & \\
\hline \multicolumn{10}{|l|}{ POL } \\
\hline \multicolumn{10}{|l|}{ Child sex } \\
\hline Female & Ref & & & Ref & & & & & \\
\hline Male & 0.21 & $(0.04,1.04)$ & 0.056 & 0.23 & $(0.04,1.34)$ & 0.101 & & & \\
\hline \multicolumn{10}{|l|}{ Father's age } \\
\hline$<40$ & Ref & & & Ref & & & & & \\
\hline$\geq 41$ & 2.36 & $(0.66,8.42)$ & 0.188 & 2.49 & $(0.49,12.69)$ & 0.272 & & & \\
\hline
\end{tabular}


Table 5 Univariate and multivariate predictors of vaccination coverage (Continued)

\begin{tabular}{|c|c|c|c|c|c|c|c|c|c|}
\hline \multicolumn{10}{|l|}{ Father's region of origin } \\
\hline Han & Ref & & & & & & & & \\
\hline Chinse-Korean (Chosun) & 2.17 & $(0.44,10.75)$ & 0.344 & & & & & & \\
\hline \multicolumn{10}{|l|}{ Father's educational level } \\
\hline Middle-High & Ref & & & Ref & & & & & \\
\hline Elementary & 0.29 & $(0.02,3.52)$ & 0.328 & 0.51 & $(0.02,11.93)$ & 0.674 & & & \\
\hline None & 0.21 & $(0.04,1.02)$ & 0.054 & 0.33 & $(0.04,3.08)$ & 0.327 & & & \\
\hline \multicolumn{10}{|l|}{ Annual income } \\
\hline$<3000$ & Ref & & & & & & & & \\
\hline$\geq 3000$ & 1.32 & $(0.37,4.69)$ & 0.671 & & & & & & \\
\hline \multicolumn{10}{|l|}{ Sibling } \\
\hline No & Ref & & & & & & & & \\
\hline Yes & - & - & - & & & & & & \\
\hline \multicolumn{10}{|l|}{ Vaccination card } \\
\hline No & Ref & & & Ref & & & & & \\
\hline Yes & 2.34 & $(0.65,8.48)$ & 0.195 & 1.43 & $(0.28,7.33)$ & 0.669 & & & \\
\hline \multicolumn{10}{|l|}{ Previous miscarriage } \\
\hline Yes & Ref & & & Ref & & & Ref & & \\
\hline No & 0.08 & $(0.02,0.33)$ & $<0.001$ & 0.11 & $(0.02,0.51)$ & 0.005 & 0.08 & $(0.02,0.33)$ & $<0.001$ \\
\hline \multicolumn{10}{|l|}{ VAR } \\
\hline \multicolumn{10}{|l|}{ Child sex } \\
\hline Female & Ref & & & Ref & & & & & \\
\hline Male & 2.93 & $(0.56,15.36)$ & 0.204 & 1.87 & $(0.32,1.99)$ & 0.488 & & & \\
\hline \multicolumn{10}{|l|}{ Father's age } \\
\hline$<40$ & Ref & & & Ref & & & Ref & & \\
\hline$\geq 41$ & 0.31 & $(0.07,1.37)$ & 0.122 & 0.10 & $(0.01,0.95)$ & 0.045 & 0.10 & $(0.01,0.95)$ & 0.045 \\
\hline \multicolumn{10}{|l|}{ Father's region of origin } \\
\hline Han & Ref & & & & & & & & \\
\hline Chinse-Korean (Chosun) & 1.40 & $(0.31,6.30)$ & 0.667 & & & & & & \\
\hline \multicolumn{10}{|l|}{ Father's educational level } \\
\hline Middle-High & Ref & & & Ref & & & Ref & & \\
\hline Elementary & - & - & - & - & - & - & - & - & - \\
\hline None & 6.90 & $(1.32,36.17)$ & 0.022 & 18.55 & $(1.67,205.8)$ & 0.017 & 21.54 & $(2.01,231.3)$ & 0.011 \\
\hline \multicolumn{10}{|l|}{ Annual income } \\
\hline$<3000$ & Ref & & & & & & & & \\
\hline$\geq 3000$ & 1.10 & $(0.25,4.92)$ & 0.901 & & & & & & \\
\hline \multicolumn{10}{|l|}{ Sibling } \\
\hline No & Ref & & & & & & & & \\
\hline Yes & 0.60 & $(0.07,5.21)$ & 0.642 & & & & & & \\
\hline \multicolumn{10}{|l|}{ Vaccination card } \\
\hline No & Ref & & & & & & & & \\
\hline Yes & 0.64 & $(0.14,2.89)$ & 0.561 & & & & & & \\
\hline \multicolumn{10}{|l|}{ Previous miscarriage } \\
\hline Yes & Ref & & & & & & & & \\
\hline No & 2.18 & $(0.39,12.20)$ & 0.374 & & & & & & \\
\hline
\end{tabular}


Table 5 Univariate and multivariate predictors of vaccination coverage (Continued)

\begin{tabular}{|c|c|c|c|c|c|c|c|c|c|}
\hline \multicolumn{10}{|l|}{$\mathrm{JE}$} \\
\hline \multicolumn{10}{|l|}{ Child sex } \\
\hline Female & Ref & & & Ref & & & & & \\
\hline Male & 2.10 & $(0.90,4.87)$ & 0.085 & 2.51 & $(0.98,6.43)$ & 0.054 & & & \\
\hline \multicolumn{10}{|l|}{ Father's age } \\
\hline$<40$ & Ref & & & Ref & & & Ref & & \\
\hline$\geq 41$ & 0.41 & $(0.16,1.00)$ & 0.050 & 0.36 & $(0.14,0.97)$ & 0.044 & 0.41 & $(0.16,1.01)$ & 0.050 \\
\hline \multicolumn{10}{|l|}{ Father's region of origin } \\
\hline Han & Ref & & & & & & & & \\
\hline Chinse-Korean (Chosun) & 0.87 & $(0.35,2.12)$ & 0.751 & & & & & & \\
\hline \multicolumn{10}{|l|}{ Father's educational level } \\
\hline Middle-High & Ref & & & & & & & & \\
\hline Elementary & 2.00 & $(0.28,14.20)$ & 0.488 & & & & & & \\
\hline None & 1.61 & $(0.37,6.93)$ & 0.523 & & & & & & \\
\hline \multicolumn{10}{|l|}{ Annual income } \\
\hline$<3000$ & Ref & & & Ref & & & & & \\
\hline$\geq 3000$ & 1.81 & $(0.77,4.24)$ & 0.172 & 2.34 & $(0.91,6.05)$ & 0.081 & & & \\
\hline \multicolumn{10}{|l|}{ Sibling } \\
\hline No & Ref & & & Ref & & & & & \\
\hline Yes & 0.35 & $(0.12,1.06)$ & 0.062 & 0.30 & $(0.09,1.04)$ & 0.057 & & & \\
\hline \multicolumn{10}{|l|}{ Vaccination card } \\
\hline No & Ref & & & Ref & & & & & \\
\hline Yes & 0.36 & $(0.13,0.97)$ & 0.042 & 0.42 & $(0.14,1.25)$ & 0.119 & & & \\
\hline \multicolumn{10}{|l|}{ Previous miscarriage } \\
\hline Yes & Ref & & & & & & & & \\
\hline No & 1.93 & $(0.55,6.79)$ & 0.307 & & & & & & \\
\hline \multicolumn{10}{|l|}{ 1:3:3:3:1 } \\
\hline \multicolumn{10}{|l|}{ Child sex } \\
\hline Female & Ref & & & Ref & & & & & \\
\hline Male & 0.49 & $(0.17,1.44)$ & 0.192 & 0.37 & $(0.18,1.89)$ & 0.370 & & & \\
\hline \multicolumn{10}{|l|}{ Father's age } \\
\hline$<40$ & Ref & & & & & & & & \\
\hline$\geq 41$ & 1.54 & $(0.54,4.38)$ & 0.422 & & & & & & \\
\hline \multicolumn{10}{|l|}{ Father's region of origin } \\
\hline Han & Ref & & & & & & & & \\
\hline Chinse-Korean (Chosun) & 1.12 & $(0.38,3.75)$ & 0.759 & & & & & & \\
\hline \multicolumn{10}{|l|}{ Father's educational level } \\
\hline Middle-High & Ref & & & Ref & & & & & \\
\hline Elementary & 0.18 & $(0.02,2.12)$ & 0.173 & 0.31 & $(0.02,4.81)$ & 0.404 & & & \\
\hline None & 0.27 & $(0.06,1.13)$ & 0.073 & 0.45 & $(0.09,2.28)$ & 0.337 & & & \\
\hline \multicolumn{10}{|l|}{ Annual income } \\
\hline$<3000$ & Ref & & & & & & & & \\
\hline$\geq 3000$ & 0.72 & $(0.24,2.12)$ & 0.547 & & & & & & \\
\hline
\end{tabular}


Table 5 Univariate and multivariate predictors of vaccination coverage (Continued)

\begin{tabular}{|c|c|c|c|c|c|c|c|c|c|}
\hline \multicolumn{10}{|l|}{ Sibling } \\
\hline No & Ref & & & Ref & & & & & \\
\hline Yes & 4.77 & $(0.59,38.64)$ & 0.143 & 2.76 & $(0.32,23.73)$ & 0.356 & & & \\
\hline \multicolumn{10}{|c|}{ Vaccination card } \\
\hline No & Ref & & & & & & & & \\
\hline Yes & 1.81 & $(0.61,5.34)$ & 0.283 & & & & & & \\
\hline \multicolumn{10}{|c|}{ Previous miscarriage } \\
\hline Yes & Ref & & & Ref & & & Ref & & \\
\hline No & 0.14 & $(0.04,0.50)$ & 0.002 & 0.18 & $(0.05,0.69)$ & 0.012 & 0.14 & $(0.04,0.50)$ & 0.002 \\
\hline
\end{tabular}

\section{Limitation of this study}

This study has a few limitations. The cross-sectional study design and retrospective assessment of vaccination rates and barriers to coverage are study limitations. Also, assessment of vaccination coverage was based on data extracted from vaccination cards, or caregiver selfreported coverage, for children for whom there was no vaccination card available. The low availability (25\%) of vaccination cards and heterogeneous data sources remains a study limitation. Additionally, although this is the largest study to date to examine vaccination rates and barriers in this population, the relatively small sample size of 91 caregivers and children and limited number of predictors assessed for vaccination coverage are study limitations. Immunization rates for KoreanChinese children were also compared to local Chinese and migrant children, using historic datasets from WHO [12] and $\mathrm{Hu}$ et al.; [15] the heterogeneous data sources limits comparability of findings. Further research is needed to examine the rates and predictors of childhood vaccinations prospectively in this high-risk refugee population.

\section{Conclusions}

In this study, vaccination rates were significantly lower in children born to North Korean refugees and Chinese men, compared to local Chinese or migrant children. Sociodemographic factors, including older paternal age and having a sibling were associated with lower odds of being vaccinated, while maternal history of miscarriage was associated with greater likelihood of being vaccinated. Additional prospective studies are needed to examine rates of immunizations and the barriers and determinants of health care access in this high-risk refugee population.

\section{Abbreviations}

BCG: tuberculosis; DTP: diphtheria-tetanus-pertussis; HBV: hepatitis B: JE: Japanese Encephalitis; MMR: measles-mumps-rubella; $\mathrm{MOH}$ : Ministry of
Health; NGO: non-governmental organization; POL: polio; VAR: varicella; WHO: World Health Organization.

\section{Competing interests}

The authors declare that they have no competing interests.

\section{Authors' contributions}

HJC designed the study, survey, and the statistical analysis and wrote the first draft of the manuscript. SHH and HK were involved in the survey design, data collection, and analysis of data. JLF provided guidance in the interpretation of findings and writing and revising the manuscript. All authors read and approved the final manuscript.

\section{Acknowledgements}

The authors are grateful to Global Together involved in the data collection process; and the Cornell Statistical Consulting Unit for their assistance with statistical analysis. No funding was received for this study.

\section{Author details}

${ }^{1}$ Cornell University, Ithaca, NY, USA. ${ }^{2}$ Yonsei University College of Medicine, 50-1 YonseiRo SeodaemunGu, 120-752 Seoul, South Korea. ${ }^{3}$ Department of Environment and Health Science, Soonchunhyang University, Asan-si, South Korea. ${ }^{4}$ Department of Health Systems and Outcomes, Johns Hopkins University School of Nursing, Baltimore, MD, USA.

Received: 13 February 2015 Accepted: 2 March 2016

Published online: 13 April 2016

\section{References}

1. Chang Y, Haggard S, Noland M. North Korean Refugees in China: Migration Experiences of North Korean Refugees: Survey Evidence from China. Washington, D.C: US Commitee for Human Rights in North Korea; 2008.

2. Gahng E. North Korean border-crossers in Yanbian: the protection Gap between the economic migrant and refugee regimes. Geo Immigr LJ. 2009; 24:361.

3. Haggard S, Noland M. Famine in North Korea: markets, aid, and reform. New York: Columbia University Press; 2007.

4. Margesson R, Chanlett-Avery E, Bruno A. North Korean Refugees in China and Human Rights Issues: International Response and U.S. Policy Options. Washington, D.C: Congressional Research Service, Library of Congress; 2007.

5. Harden, B. North Korean Women Who Try to Flee to China Encounter Abuse at Home and Abroad. Washington Post. Wednesday, June 10, 2009. http://www.washingtonpost.com/wp-dyn/content/article/2009/06/09/ AR2009060903143.html.

6. Kim J. Trafficked: domestic violence, exploitation in marriage, and the foreign-bride industry. Virginia Journal of International Law. 2011;51:443.

7. United States. Congressional-Executive Commission on China. The plight of North Koreans in China : a current assessment : roundtable before the Congressional-Executive Commission on China, One Hundred Eighth 
Congress, second session, April 19, 2004. Washington; U.S: G.P.O. : For sale by the Supt. of Docs., U.S. G.P.O; 2004.

8. Hong C. The fiction of the North Korean refugee orphan. 38 North: Informed Analysis of North Korea [Internet]. http://38north.org/2012/09/ chong091912/ [19 Sep 2012].

9. Durrheim DN, Cashman P. Addressing the immunization coverage paradox: a matter of children's rights and social justice. Clin Ther. 2010;32:1496-8.

10. Ministry of Health. National immunization program review. China; 2004.

11. Ministry of Health. Technological standards for expanded program on immunization. China; 2005. Available at http://www.gov.cn/yjg//2005-10/14/ content 77713.htm.

12. World Health Organization. WHO Vaccine Preventable Diseases Monitoring System: 2012 Global summary - Country Profile: China. Geneva: WHO; 2012.

13. Chen YP, Chen EF, Li Q, Hu Y, Qi X-H, Ling LY. Evaluation on surveillance of routine immunization coverage rate in Zhejiang province, 2005-2009. Dis Surveill. 2011;26:33-5.

14. Sun M, Ma R, Zeng Y, Luo F, Zhang J, Hou W. Immunization status and risk factors of migrant children in densely populated areas of Beijing China. Vaccine. 2010;28:1264-74.

15. Hu Y, Chen E, Li Q, Chen Y, Qi X. Immunization coverage and its determinants among children born in 2008-2009 by questionnaire survey in Zhejiang China. Asia Pac J Public Health. 2011 (in press).

16. United States. Congress. House. Committee on International Relations. Subcommittee on Asia and the Pacific., United States. Congress. House. Committee on International Relations. Subcommittee on Africa Global Human Rights and International Operations. North Korea : human rights update and international abduction issues : joint hearing before the Subcommittee on Asia and the Pacific and the Subcommittee on Africa, Global Human Rights and International Operations of the Committee on International Relations, House of Representatives, One Hundred Ninth Congress, second session, April 27, 2006. Washington; U.S: G.P.O. : For sale by the Supt. of Docs., U.S. G.P.O; 2006.

17. Duclos P, Okwo-Bele JM, Gacic-Dobo M, Cherian T. Global immunization: status, progress, challenges and future. BMC Int Health Hum Rights. 2009;9 Suppl 1:S2.

18. Rammohan A, Awofeso N, Fernandez RC. Paternal education status significantly influences infants' measles vaccination uptake, independent of maternal education status. BMC Public Health. 2012;12:336.

19. Dombkowski KJ, Lantz PM, Freed GL. Risk factors for delay in ageappropriate vaccination. Public Health Rep. 2004;119:144-55.

20. Lieu TA, Black SB, Ray P, Chellino M, Shinefield HR, Adler NE. Risk factors for delayed immunization among children in an HMO. Am J Public Health. 1994;84:1621-5.

21. Theeten H, Hens N, Vandermeulen C, Depoorter AM, Roelants M, Aerts M, et al. Infant vaccination coverage in 2005 and predictive factors for complete or valid vaccination in Flanders Belgium: an EPI-survey. Vaccine. 2007;25:4940-8.

22. Danis K, Georgakopoulou T, Stavrou T, Laggas D, Panagiotopoulos T. Socioeconomic factors play a more important role in childhood vaccination coverage than parental perceptions: a cross-sectional study in Greece. Vaccine. 2010;28:1861-9.

23. Bobo JK, Gale JL, Thapa PB, Wassilak SG. Risk factors for delayed immunization in a random sample of 1163 children from Oregon and Washington. Pediatrics. 1993;91:308-14.

24. Matsumura T, Nakayama T, Okamoto $\mathrm{S}$, Ito $\mathrm{H}$. Measles vaccine coverage and factors related to uncompleted vaccination among 18-month-old and 36month-old children in Kyoto Japan. BMC Public Health. 2005:5:59.

25. Swennen B, Van Damme P, Vellinga A, Coppieters Y, Depoorter AM. Analysis of factors influencing vaccine uptake: perspectives from Belgium. Vaccine. 2001;20 Suppl 1:S5-7. discussion S1.

\section{Submit your next manuscript to BioMed Central and we will help you at every step:}

- We accept pre-submission inquiries

- Our selector tool helps you to find the most relevant journal

- We provide round the clock customer support

- Convenient online submission

- Thorough peer review

- Inclusion in PubMed and all major indexing services

- Maximum visibility for your research

Submit your manuscript at www.biomedcentral.com/submit
Biomed Central 